\title{
Atmospheric Emissions of As, Sb, and Se from Coal Combustion in Shandong Province, 2005-2014
}

\author{
Jianxin Fan', Yong Wang'* \\ ${ }^{1}$ Key Laboratory of Hydraulic and Waterway Engineering of the Ministry of Education, Chongqing Jiaotong University, \\ Chongqing 400074, China \\ ${ }^{2}$ School of Economics and Management, Chongqing Jiaotong University, Chongqing 400074, China
}

Received: 7 April 2016

Accepted: 11 June 2016

\begin{abstract}
The emissions of hazardous trace elements have gained considerable attention because of their negative impacts on local air quality, regional environmental health, and ecological risks. Shandong Province has been considered to be the top provincial emitter of $\mathrm{Sb}$, As, and $\mathrm{Se}$ in China owing to rapid economic development and its energy consumption structure (mainly coal). In this study we investigate the atmospheric emissions of Sb, As, and Se from coal combustion in Shandong from 2005 to 2014, and we analyze a scenario for future emissions from coal-fired power plants. The inventory is based on the following parameters: coal consumption, economic sectors, boiler types, and air pollution control technologies. Results indicate that the calculated provincial total emissions of $\mathrm{Sb}$, As, and Se from coal combustion in 2005 were estimated at $40.26,246.5$, and $255.9 \mathrm{t}$, respectively, and increased to $51.36,311.9$, and $313.9 \mathrm{t}$ by 2014 with annual growth rates of $2.75 \%, 2.65 \%$, and $2.27 \%$. Industrial use was the largest single sector, accounting for nearly $83.2 \%, 82.6 \%$, and $74.2 \%$ of the provincial total emissions for $\mathrm{Sb}$, As, and $\mathrm{Se}$ in 2014 , respectively. The emissions from coal-fired power plants have been controlled by the installation of flue gas desulfurization systems. In addition, scenario analysis shows that $\mathrm{Sb}$ and $\mathrm{As}$ emissions from coal-fired power plants will decrease in the future in a high-efficiency control technology scenario. However, Se emissions in 2030 will still be higher than in 2014. This study demonstrates the importance of assessing the effectiveness of control measures and supplying necessary suggestions for managing coal combustion in Shandong.
\end{abstract}

Keywords: atmospheric emission; coal combustion; Sb, As, and Se; coal-fired power plants

\section{Introduction}

Shandong Province is located in eastern China and has a very important function in the nation's development.

*e-mail: yongwx6@gmail.com
However, its developing industry and coal-dominated energy structure have induced numerous environmental problems, such as photochemical smog and haze [1]. Although Shandong's environmental statistics data show that air pollution was alleviated after enacting a series of pollution control policies, $\mathrm{PM}_{10}, \mathrm{PM}_{2.5}, \mathrm{SO}_{2}$, and $\mathrm{NO}_{2}$ are still major air pollutants. In 2014, $\mathrm{PM}_{10}, \mathrm{PM}_{2.5}, \mathrm{SO}_{2}$, and 
$\mathrm{NO}_{2}$ reached concentrations of $142,82,59$, and $46 \mu \mathrm{g} / \mathrm{m}^{3}$, respectively [2] - higher than or close to the second-grade standard of the state $\left(70,35,60,40 \mu \mathrm{g} / \mathrm{m}^{3}\right.$ for $\mathrm{PM}_{10}, \mathrm{PM}_{2.5}$, $\mathrm{SO}_{2}$, and $\mathrm{NO}_{2}$, respectively). Most air pollution comes from industry product processes where coal combustion is the key source $[3,4]$.

Trace elements (including $\mathrm{Sb}, \mathrm{As}$, and $\mathrm{Se}$ ) are released from coal through smoke and are absorbed to particle matters in the atmosphere [5]. These trace elements will have a negative effect on human health via respiration. They will also travel long distances and be deposited into soils, water bodies, and plant leaves via wet and dry deposition, leading to a potential risk to the local environment [6-7]. The harmful impacts of $\mathrm{Sb}$, As, and Se on the environment and public health were widely reported [8-11]. Cases of endemic arsenism caused by coal burning have been found in many Chinese provinces $[6,12]$, and more than 16,000 people have suffered from arsenism caused by coal burning [13]. Although $\mathrm{Se}$ is an essential trace element for humans and animals, high concentrations of it are harmful. Long-term exposure to high concentrations of Se may even result in hair and nail loss, and nervous system disorders [14]. Many cases of selenosis have been reported in regions with high Se concentrations [15]. Antimony and its compounds are listed as prior pollutants by the US Environmental Protection Agency and the EU because of its toxicity and suspected carcinogenic properties [10]. Antimony is released into the environment from coal combustion via two primary pathways: atmospheric emissions as volatile phases and the leachable portion of solid combustion byproducts [16-17].

Coal combustion is one of the main anthropogenic sources of hazardous trace elements such as $\mathrm{Sb}$, As, and Se [18-20], and their increased emissions with rising coal consumption has led to serious environmental pollution [21]. Given the large coal consumption in power plants and industry sectors in Shandong, $\mathrm{Sb}$, As, and Se emissions are considered to be the highest in China [12, 14, 21].

Previous studies have focused primarily on conventional air pollutant emissions from coal combustion, such as $\mathrm{SO}_{2}, \mathrm{NO}_{x}, \mathrm{PM}$, and $\mathrm{Hg}$ [20, 22-23]. Zhao et al. established a unit-based inventory of $\mathrm{SO}_{2}, \mathrm{NO}_{x}$, and PM emissions from coal-fired power plants in China [24]. Xiong et al. reported the emission inventories of $\mathrm{SO}_{2}, \mathrm{NO}_{\mathrm{x}}, \mathrm{PM}_{2.5}$, and $\mathrm{Hg}$ from coal-fired power plants in Shandong in 2012 [23]. Tian et al. found that Shandong is the biggest contributor to $\mathrm{Sb}, \mathrm{As}$, and $\mathrm{Se}$ emissions in China $[13,21,25]$. Meanwhile, the atmospheric emissions of $\mathrm{Hg}$, As, and Se from coal combustion in China rapidly increased from 1980 to 2007, and Shandong is still the largest contributor [12, 16]. Cheng et al. [26] investigated the inventory of atmospheric emissions of $\mathrm{Hg}, \mathrm{As}, \mathrm{Pb}, \mathrm{Cd}$, and $\mathrm{Cr}$ from anthropogenic sources in China from 2000 to 2010, and found that coal consumption resulted in the ascending total emissions of heavy metals.

Various policies and regulations have been enacted in China to restrict the increasing emissions of trace elements from fuel combustion and industrial processes, including the Emission Standard of Air Pollutants for Thermal Power Plants (GB13223-2011) [27-28] and the Air Pollution Control Plan for Shandong Province during 2013-20. Additionally, some specific targets were set with detailed technological methods to reduce the air pollutants in the province [23]. As a result, the adjustment and optimization of industrial structures occurred, consequently changing the emissions of $\mathrm{Sb}, \mathrm{As}$, and $\mathrm{Se}$ to some extent.

However, the emission inventories of $\mathrm{Sb}, \mathrm{As}$, and $\mathrm{Se}$ from coal combustion were evaluated at the national level. Few estimates of Sb, As, and Se emissions in Shandong Province have been published. In this paper evaluates the historical trends and characteristics of anthropogenic atmospheric emissions of $\mathrm{Sb}$, As, and $\mathrm{Se}$ from coal combustion during 2005-14. Additionally, the temporal atmospheric emission inventories of $\mathrm{Sb}$, As, and Se have been developed by economic sectors. Finally, the future emissions from coal-fired power plants are predicted by a scenario methodology.

\section{Methods and Materials}

To evaluate the emissions of $\mathrm{Sb}, \mathrm{As}$, and $\mathrm{Se}$ from coal combustion, the emission amounts are calculated using different sectional coal consumption data and detailed emission factors. The basic equations can be expressed as follows:

$$
\begin{gathered}
E F_{i, \mathrm{a}}=\sum_{j} \sum_{m} \sum_{n} C_{i, a} \times R_{j} \times\left(1-P_{D C(m)}\right) \times\left(1-P_{S O_{2}(n)}\right) \\
E_{i, a}=M_{i, a} \times E F_{i, a} \\
E_{a_{\text {Total }}}=\sum_{i} E_{a, i}
\end{gathered}
$$

... where $E F_{i, a}$ is the emission factor of $\mathrm{Sb}$, As, or Se from $i$ sector in year $a ; E_{i, a}$ is the emission of atmospheric $\mathrm{Sb}$, As, or Se from $i$ sector in year $a ; E_{\mathrm{a}_{\text {Total }}}$ is the atmospheric emission of $\mathrm{Sb}, \mathrm{As}$, or Se in year $a$; $C$ is the average content of $\mathrm{Sb}, \mathrm{As}$, or $\mathrm{Se}$ in the coal consumed in Shandong; $M$ is coal consumption; $R$ is the fraction of $\mathrm{Sb}, \mathrm{As}$, or $\mathrm{Se}$ atmospherically released from coal combustion; $P_{D C}$ and $P_{\mathrm{SO}_{2}}$ are the removal efficiencies of the installed dust collectors and desulfurization devices, respectively; $i$ represents the emission source classified by economic sectors; $j$ represents the boiler type; $m$ represents the dust collector type; $n$ represents the desulfurization devices type; and $a$ is the year.

\section{Data Collection}

The atmospheric emissions of $\mathrm{Sb}, \mathrm{As}$, and $\mathrm{Se}$ from coal combustion are the most important sources of anthropogenic discharge in Shandong $[16,29]$. Coal is 
Table 1. Release ratios of $\mathrm{Sb}, \mathrm{As}$, and Se from different boiler types.

\begin{tabular}{|c|c|c|c|c|}
\hline \multirow{2}{*}{ Boiler type } & \multicolumn{3}{|c|}{ Release rate (\%) } & \multirow{2}{*}{ References } \\
\cline { 2 - 4 } & $\mathrm{Sb}$ & $\mathrm{As}$ & $\mathrm{Se}$ & \\
\hline $\begin{array}{c}\text { Pulverized-coal } \\
\text { boiler }\end{array}$ & 89.40 & 98.46 & 96.22 & {$[9,10,26]$} \\
\hline Stoker fired boiler & 53.50 & 77.18 & 80.95 & {$[9]$} \\
\hline $\begin{array}{c}\text { Fluidized-bed } \\
\text { furnace }\end{array}$ & 74.40 & 75.60 & 98.05 & $\begin{array}{c}{[9,32,38-} \\
39]\end{array}$ \\
\hline Coke furnace & 70.00 & 30.00 & 40.00 & {$[29,40]$} \\
\hline
\end{tabular}

mainly consumed in four economic sectors, i.e., coalfired power plants, industrial coal usage, residential coal usage, and other coal use. Therefore, coal consumption by those sectors was cited from the China Energy Statistical Yearbook and Shangdong Statistical Yearbook (20062015) [30-31].

\section{Category-Specific Emission Factors}

The emission factors of $\mathrm{Sb}, \mathrm{As}$, and $\mathrm{Se}$ are determined by various factors, such as the patterns of combustion facilities and air pollution control devices (APCDs). Coal combustion facilities in the power plant, industrial, and other sectors can be divided into four types: stoker-fired boiler, circulating fluidized bed boiler, pulverized coal (PC) boiler, and coke furnace. The emission factors of $\mathrm{Sb}$, As, and Se of each boiler type are listed in Table 1.

The APCDs include electrostatic precipitators (ESPs), fabric filters (FFs), cyclones, wet scrubbers, and flue gas desulfurization (FGD). Owing to the slight changes of $\mathrm{PM} / \mathrm{SO}_{2}$ removal efficiencies during the past decade [17, $18,32-34]$, the constant average removal efficiencies of APCDs were adopted instead of the varied removal efficiencies. In fact, the most important factor that influences the removal of $\mathrm{Sb}, \mathrm{As}$, and $\mathrm{Se}$ emissions is the increased installation proportion of APCDs with a high $\mathrm{PM} / \mathrm{SO}_{2}$ removal efficiency. The removal efficiencies of $\mathrm{Sb}$, As, and $\mathrm{Se}$ of different APCDs are presented in Table 2.

By the end of 2010, the proportion of ESPs installed in PC power units reached nearly $93 \%$, while the FFs

Table 2. Removal efficiencies of $\mathrm{Sb}$, As, and Se by different control devices.

\begin{tabular}{|c|c|c|c|c|}
\hline \multirow{2}{*}{ Category } & \multicolumn{3}{|c|}{ Removal efficiencies (\%) } & \multirow{2}{*}{ References } \\
\cline { 2 - 5 } & $\mathrm{Sb}$ & $\mathrm{As}$ & $\mathrm{Se}$ & \\
\hline ESP & 83.5 & 86.20 & 73.78 & {$[10]$} \\
\hline FF & 94.3 & 99.00 & 65 & {$[10]$} \\
\hline Cyclone & 40 & 43.00 & 40 & {$[10,41]$} \\
\hline WFGD & 82.1 & 80.38 & 74.87 & {$[10,21]$} \\
\hline Wet Scrubber & 96.3 & 96.30 & 85 & {$[10,42]$} \\
\hline
\end{tabular}

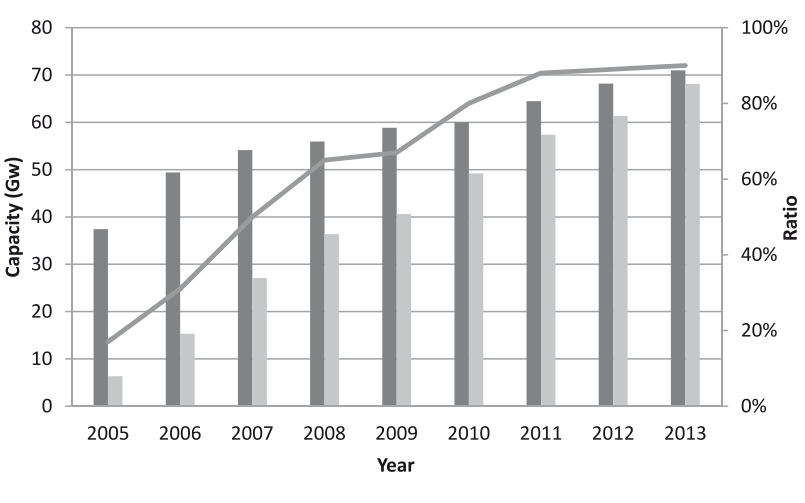

Capacity of power plants Capacity of power plants with FGD $\longrightarrow$ Ratio of FGD

Fig. 1. The trend of proportion of power plants with FGD devices in Shandong, 2005-2014.

Data from Shandong Statistical Yearbook [30].

and electrical bag filters accounted for the remaining 7\% [26]. All the fluidized bed furnaces were equipped with ESPs. The installation of FGD is very important to trace element removal [35]. Thus, the FGD installed ratio was considered in this paper, and data were collected from the China Electric Power Yearbook [31]. The increased proportion of power plants with FGD devices and the installed ratio in Shandong are shown in Fig. 1.

The average contents of $\mathrm{Sb}, \mathrm{As}$, and $\mathrm{Se}$ in consumptive coal are $0.71,5.05$, and $2.76 \mathrm{mg} / \mathrm{kg}$, respectively, as calculated by Tian et al. $[29,36]$.

\section{Scenario Projections}

To achieve the goal of energy conservation and emission reduction, three emission scenarios were developed for coal-fired power plants in Shandong to 2030 (Table 3) [1, 37]. All newly built units were assumed to be installed with wet FGD and nearly one-third equipped with $\mathrm{FF} / \mathrm{EF}$ in scenarios [23]. In the businessas-usual scenario (BAU), emissions were evaluated by the current APCD installation ratios. The best-availablecontrol-technology (BACT) is on the basis of the 2015 emission reduction target. The control technologies will continue to improve in the future. In the high-efficiency control technology (HECT), we assume that the control technology penetration would be stricter than that of the BACT scenario.

\section{Results and Discussion}

\section{Coal Consumption}

Coal consumption of the four economic sectors and the types of coal products are collected from the Shandong Energy Statistical Yearbooks from 2006 to 2015 [30]. In 2005 , the total coal consumption in Shandong was only $260.6 \mathrm{Mt}$ of raw coal, and 105.6 and $140.7 \mathrm{Mt}$ by the coalfired power plants and industrial sectors, respectively. Because of the relatively rapid economic growth in 
Table 3. Assumptions of activity levels and control technology penetrations.

\begin{tabular}{|c|c|c|c|c|c|}
\hline Years & Scenarios & Coal consumption (Mt) & WFGD & ESP & $\mathrm{FF} / \mathrm{EF}$ \\
\hline 2014 & BASE & 146.57 & $91 \%$ & $99 \%$ & $1 \%$ \\
\hline \multirow{3}{*}{2017} & BAU & 186.32 & $93 \%$ & $92 \%$ & $8 \%$ \\
\hline & BACT & 186.32 & $94 \%$ & $91 \%$ & $9 \%$ \\
\hline & HECT & 186.32 & $96 \%$ & $90 \%$ & $10 \%$ \\
\hline \multirow{3}{*}{2020} & BAU & 232.3 & $94 \%$ & $86 \%$ & $14 \%$ \\
\hline & BACT & 232.3 & $96 \%$ & $81 \%$ & $19 \%$ \\
\hline & HECT & 232.3 & $99 \%$ & $77 \%$ & $23 \%$ \\
\hline \multirow{3}{*}{2025} & BAU & 259.7 & $95 \%$ & $82 \%$ & $18 \%$ \\
\hline & BACT & 259.7 & $99 \%$ & $70 \%$ & $30 \%$ \\
\hline & HECT & 259.7 & $100 \%$ & $65 \%$ & $35 \%$ \\
\hline \multirow{3}{*}{2030} & BAU & 267.5 & $93 \%$ & $80 \%$ & $20 \%$ \\
\hline & BACT & 267.5 & $100 \%$ & $60 \%$ & $40 \%$ \\
\hline & HECT & 267.5 & $100 \%$ & $56 \%$ & $44 \%$ \\
\hline
\end{tabular}

Shandong, its coal consumption increased steadily and quickly, especially from 2005 to 2010 (Fig. 2). By the end of 2014, the total coal consumption in Shandong reached 395.6 Mt. Moreover, the power plant sector was the largest consumer in total coal consumption, followed by the industrial sector. Residential use and other use sectors accounted for only a small proportion of the total coal consumption in Shandong. However, the growth rate has been falling since 2010, and total coal consumption decreased after 2011. The major reason for the decrease is the change in energy consumption composition.

In China, although total energy consumption increased rapidly after 2001, the percentage of coal consumption declined after 2006, and to $66 \%$ in 2013 (Fig. 3). Both the percentages of natural gas and green energy (such as hydropower, nuclear power, and wind power) increased

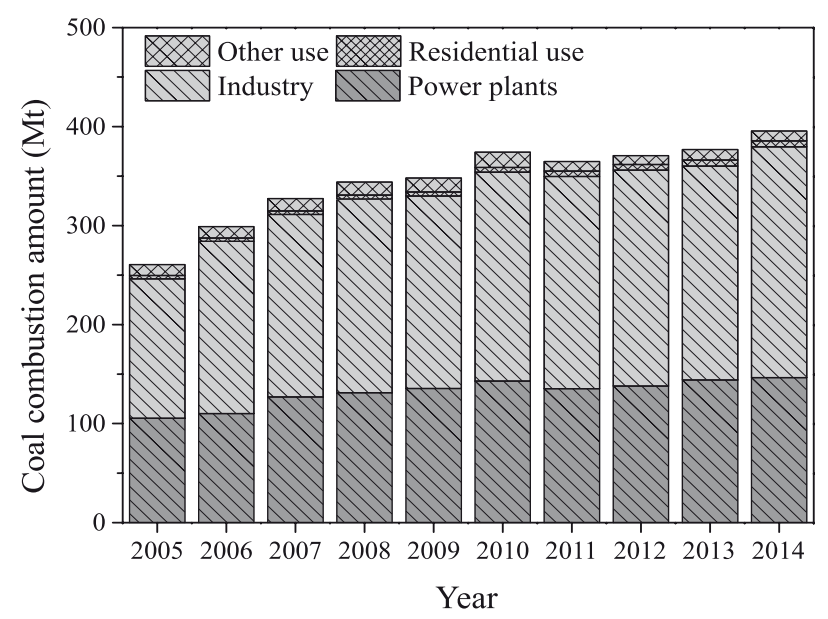

Fig. 2. Trend of coal consumption by different sectors in Shandong province, 2005-2014. during the mentioned years. Specifically, the percentage of green energy continued to increase to $11.2 \%$ by 2014 , with an annual growth rate of $5.00 \%$. Thus the use of clean and high-quality energy, such as hydro-power, natural gas, wind power, and nuclear power, was introduced to optimize the energy structure.

\section{Emission Factors of $\mathrm{Sb}$, As, and Se from Coal-fired Power Plants}

The emission factors of Sb, As, and Se from coal-fired power plants are related to its concentrations in coals, coal-burning modes, and types and quantities of installed APCDs. The final combined emission factors of $\mathrm{Sb}, \mathrm{As}$, and Se are calculated to reflect the emission levels through burning per Mt coal in power plants in Shandong (Fig. 4). The larger the final combined emission factors, the larger the amount of emissions from the burning of every ton of raw coal. Emission factors are directly proportional to the $\mathrm{Sb}$, As, and Se contents in coal and the release rates, but inversely related to the removal efficiencies of APCDs. The emission factors of these three elements declined with

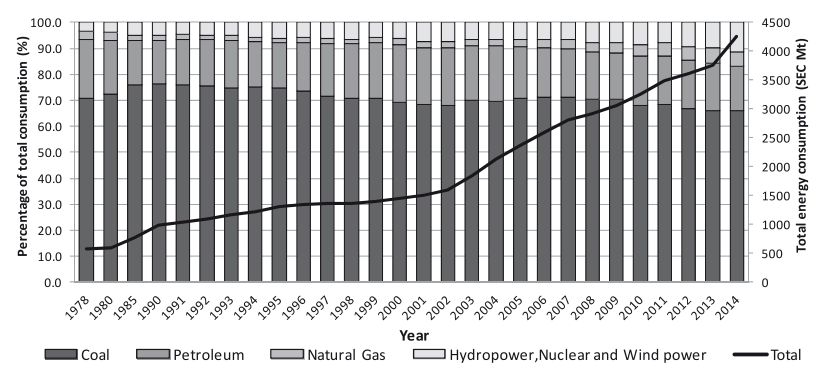

Fig. 3. Trend of total consumption of energy and its composition in China, 1978-2014.

Data from China Statistical Yearbook 2015 [31]. 


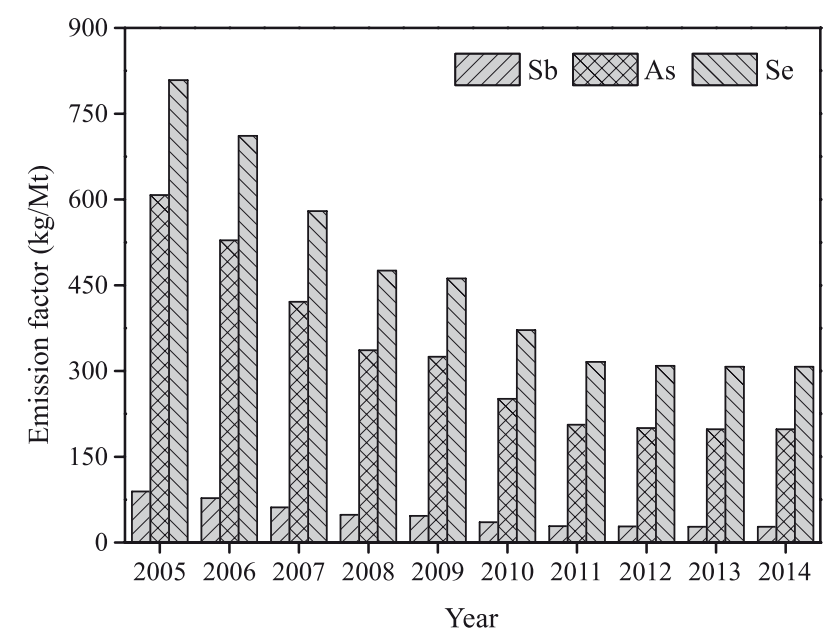

Fig. 4. Emission factors of Sb, As, and Se from coal-fired power plants of Shandong, 2005-2014.

the installed FGD equipment every year. A remarkable difference exists not only in the emission factors of different years, but also among $\mathrm{Sb}, \mathrm{As}$, and $\mathrm{Se}$.

\section{Emissions by Sectors}

The trends of $\mathrm{Sb}, \mathrm{As}$, and $\mathrm{Se}$ emissions by different economic sectors from 2005 to 2014 are illustrated in Figs $3-5$, respectively. The provincial total emissions of $\mathrm{Sb}, \mathrm{As}$, and Se from coal in 2005 are estimated at 40.26, 246.5, and $255.9 \mathrm{t}$, and increased to $51.35,311.9$, and $313.9 \mathrm{t}$ in 2014 , with annual growth rates of $2.75 \%, 2.65 \%$, and $2.27 \%$, respectively.

The Sb emissions from the four economic sectors was calculated (Fig. 5). The power plants and industrial use are two major contributors to atmospheric Sb emissions, especially for industrial use. However, $\mathrm{Sb}$ emissions from the power plant sector have decreased every year. For example, $\mathrm{Sb}$ emissions from coal-fired power plants totaled $9.45 \mathrm{t}$ in 2005 , contributing to $23.5 \%$ of total $\mathrm{Sb}$

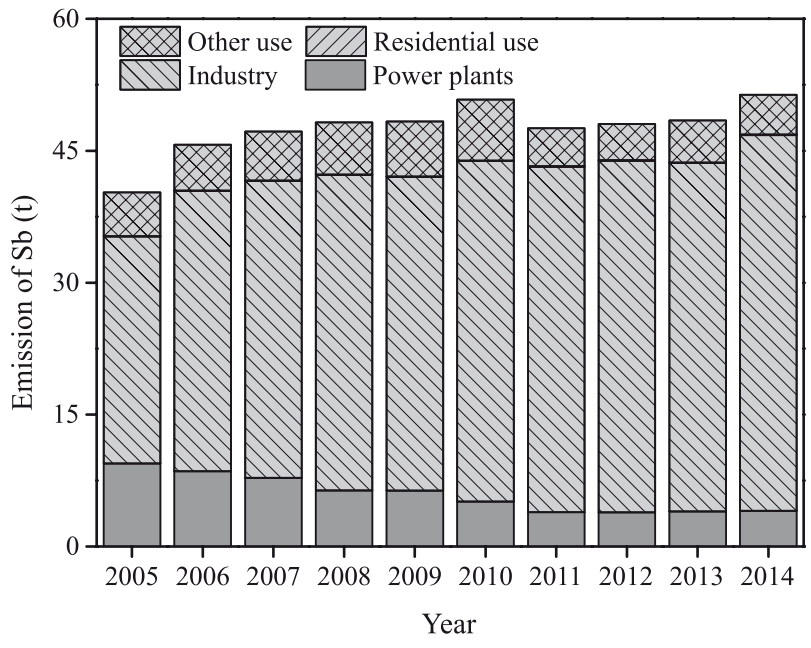

Fig. 5. Historical trends of annual Sb emissions, 2005-2014.

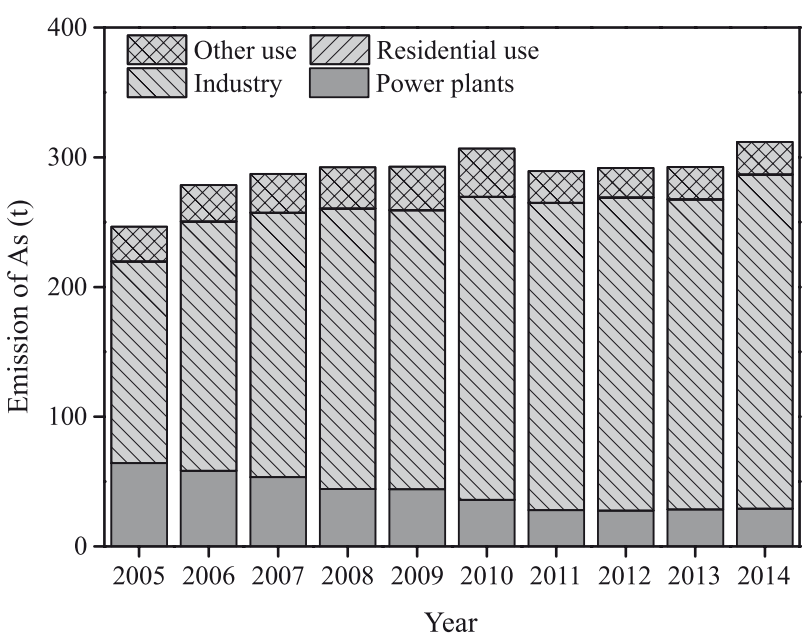

Fig. 6. Historical trends of annual As emissions, 2005-2014.

emissions. And $\mathrm{Sb}$ emissions decreased to $4.05 \mathrm{t}$ in 2014, accounting for only $7.89 \%$ of the total. However, $\mathrm{Sb}$ emissions in industrial use reached $42.73 \mathrm{t}$ in 2014 , with an average annual growth rate of $7.28 \%$.

The emissions of As and Se from the four economic sectors are shown in Figs 6, 7. The trends of As and Se emissions from the power plant sector are similar to that of Sb. The emissions of As and Se reached 64.16 and $85.35 \mathrm{t}$, contributing to $26.0 \%$ and $33.3 \%$ of total emissions in 2005. And its amounts decreased to 29.04 and $45.06 \mathrm{t}$ in 2014. However, the emissions of As and Se from the industrial use sector have been increasing since 2005, reaching 257.6 and $233.1 \mathrm{t}$ in 2014. In addition, residential use sector emissions of As and Se increased from 2005 to 2014. Because of the use of clean fuels such as natural gas and electricity, especially in urban areas, other uses of coal decreased after 2010. Accordingly, the emissions of Sb, As, and Se dropped. The emissions of Sb, As, and Se are estimated to decrease with coal consumption reductions in the other use sector, including farming, construction, transportation, and commerce. The emissions of $\mathrm{Sb}, \mathrm{As}$,

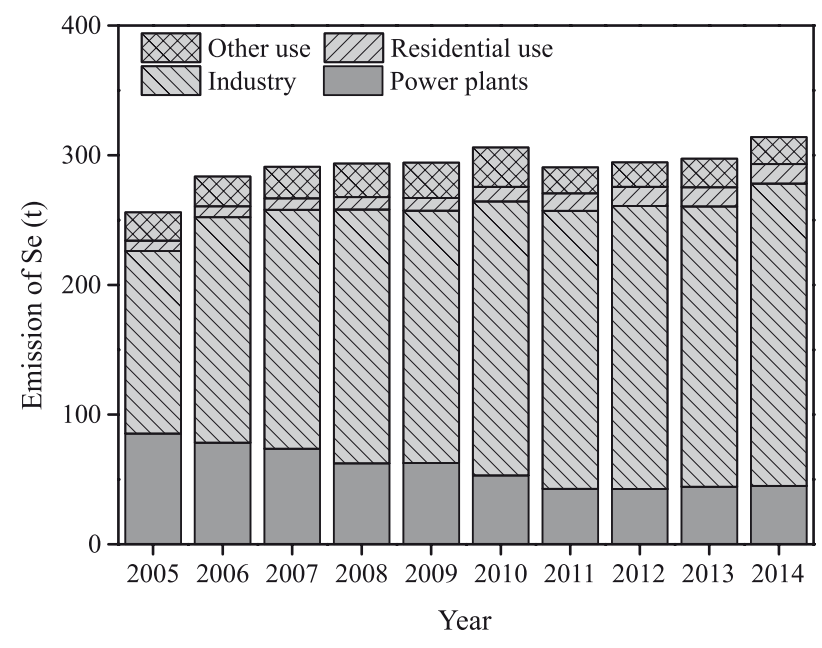

Fig. 7. Historical trends of annual Se emissions, 2005-2014. 
and Se from other uses reached 4.51, 25.0, and $20.9 \mathrm{t}$ in 2014, respectively.

The reasons for the results are:

1. Power plants and industrial use sectors are the main consumers in Shandong.

2. The decreased emissions of $\mathrm{Sb}, \mathrm{As}$, and $\mathrm{Se}$ from the power plant sector are ascribed to the change in emission factors as a result of the increasing number of power plants installed with APCDs, including ESPs and the FGD system.

3. The industrial use sector contains a significantly higher share of uncontrolled or poorly controlled boilers.

4. The rapid development of construction, transportation, and commerce enhances the emissions of $\mathrm{Sb}, \mathrm{As}$, and Se from other sectors.

With the start of the $11^{\text {th }}$ Five Years Plan (FYP) (2006-2010), the atmospheric emissions of heavy metals in China have grown at a more moderate pace owing to the comprehensive effects of the increasing application of advanced APCDs and the slower growth of fuel consumption and output of industrial products [26]. From 2001 to 2005, the annual increasing rate of coal consumption in Shandong was $26.9 \%$, but only $6.27 \%$ during 2006 and 2010. Moreover, the change in energy structure - especially the increase in clean energy constrained the growth of coal consumption. The industrial use sector became the largest consumer with the highest annual growth rate (Fig. 2). The electricity output from clean energy in Shandong, including hydropower, nuclear power, and wind power, is rapidly developing (Fig. 8).

\section{Scenario Analysis for Future Emissions from Coal-Fired Power Plants}

Air pollution policies, especially for controlling air pollutant emission from coal-fired power plants, were issued during the $12^{\text {th }}$ FYP $[1,27-28]$. Therefore, the emissions of $\mathrm{Sb}, \mathrm{As}$, and Se from coal-fired power plants could be alleviated with the tightening controls in Shandong. Based on the three scenarios, the predicted emissions from the coal power sector under these three

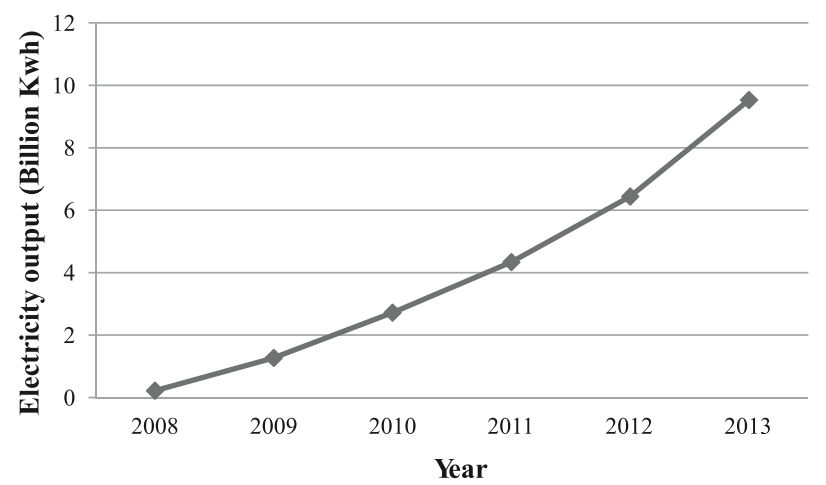

Fig. 8. Trend of electricity output from clean energy (hydropower, nuclear power, wind power, and others) in Shandong, 2008-2013. Data from Shandong Statistical Yearbook [30].
Table 4. Projected emissions (tons) from Shandong coalfired power plants in 2017, 2020, 2025, and 2030 under three scenarios.

\begin{tabular}{|c|c|c|c|c|}
\hline Years & Scenarios & $\mathrm{Sb}$ & $\mathrm{As}$ & $\mathrm{Se}$ \\
\hline 2014 & BASE & 3.86 & 27.72 & 43.27 \\
\hline \multirow{3}{*}{2017} & BAU & 4.37 & 30.952 & 53.31 \\
\cline { 2 - 5 } & BACT & 4.19 & 29.66 & 52.05 \\
\cline { 2 - 5 } & HECT & 3.86 & 27.43 & 49.45 \\
\hline \multirow{3}{*}{2020} & BAU & 5.04 & 35.10 & 65.18 \\
\cline { 2 - 5 } & BACT & 4.51 & 31.05 & 61.66 \\
\cline { 2 - 5 } & HECT & 3.89 & 26.52 & 56.01 \\
\hline \multirow{3}{*}{2025} & BAU & 5.28 & 36.34 & 70.94 \\
\cline { 2 - 5 } & BACT & 4.09 & 27.20 & 61.13 \\
\cline { 2 - 5 } & HECT & 3.75 & 24.45 & 57.47 \\
\hline \multirow{3}{*}{2030} & BAU & 5.76 & 39.08 & 76.95 \\
\cline { 2 - 5 } & BACT & 3.70 & 23.45 & 57.12 \\
\cline { 2 - 5 } & HECT & 3.57 & 22.07 & 55.19 \\
\hline
\end{tabular}

types of control levels are still high (Table 4, Figs. 9-10). The emissions of Sb, As, and Se increase by $13.4 \%, 11.6 \%$, and $23.2 \%$ in the 2017 BAU scenario compared with that of the 2014 BASE scenario, with a $27.6 \%$ increase in coal consumption. The emissions of $\mathrm{Sb}, \mathrm{As}$, and Se from coal-fired power plants in the BACT scenario increase by $8.69 \%, 7.03 \%$, and $20.3 \%$ compared to the baseline emissions in 2014.

However, in the HECT scenario of 2017, emissions of As were reduced by $1.01 \%$, while Se emissions increased by $14.3 \%$. In contrast, the emissions of $\mathrm{Sb}$ and As from coal-fired power plants will decrease in the 2030 BACT and 2030 HECT scenarios, with $40 \%$ and $44 \%$ ratios of installed FFs, respectively. Due to the relatively lower co-benefit removal efficiency of ESP/FFs and WFGD (Table 2), the Se emissions under the BACT and HECT

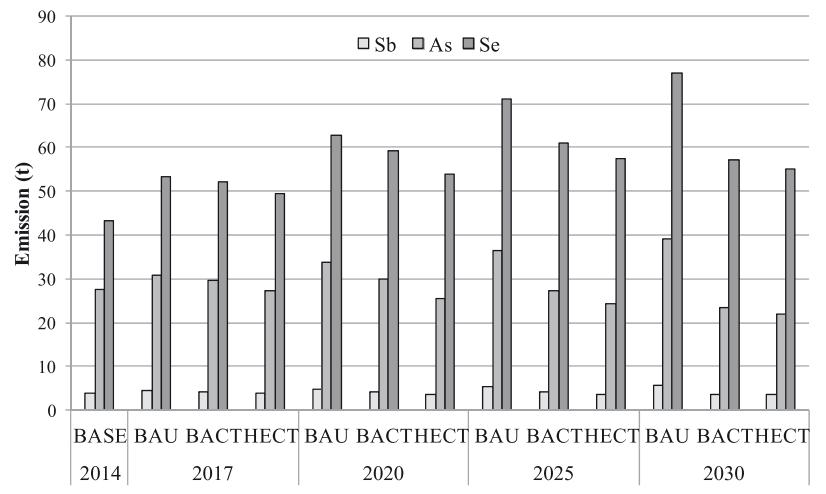

Fig. 9. Projected $\mathrm{Sb}, \mathrm{As}$, and Se emissions from coal-fired power plants in Shandong Province in 2017, 2020, 2025, and 2030 under three scenarios. 

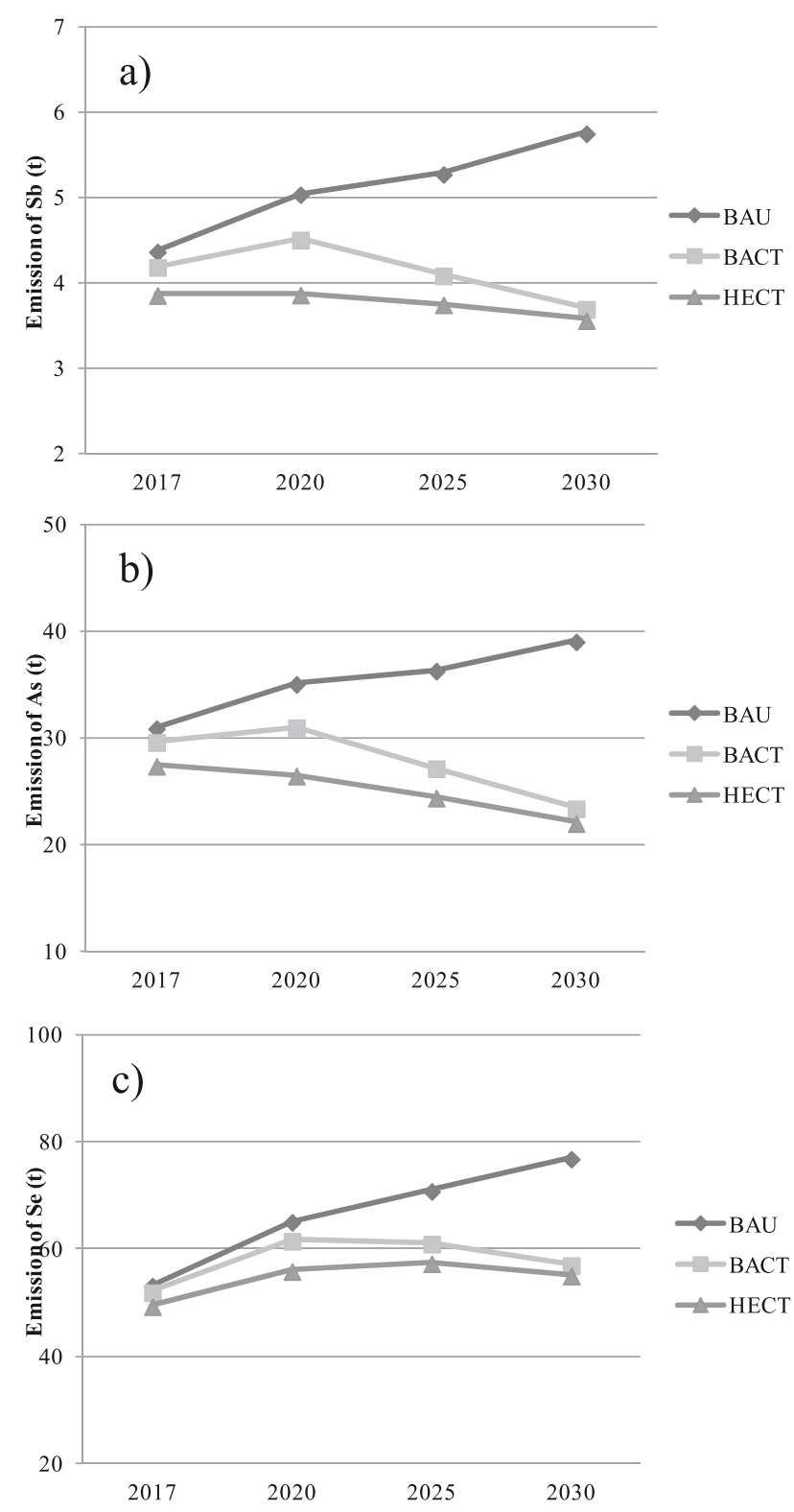

Fig. 10. Projected $\mathrm{Sb}$ (a), As (b), and $\mathrm{Se}$ (c) emissions from Shandong coal-fired power plants.

scenarios in 2030 are still higher than those in 2014. Fortunately, the predicted Se emissions under the HECT scenarios will begin to decrease after 2025 . Thus, the FFs combined with the WFGD system is the best choice to control the emissions of $\mathrm{Sb}, \mathrm{As}$, and $\mathrm{Se}$ to date. In the future, innovative multi-pollutant control technology may be available as the more cost-effective way to further diminish trace element emissions.

\section{Uncertainties Analysis}

The emissions of Sb, As, and Se are affected by several factors, and some uncertainties remain in the estimation of $\mathrm{Sb}, \mathrm{As}$, and $\mathrm{Se}$ emissions from coal combustion in Shandong. Firstly, the significant discrepancies are observed in the estimates of the typical $\mathrm{Sb}$, As, and $\mathrm{Se}$ contents in coals. Secondly, the combustion release rates and emission factors at different burners are improvable. Finally, the determination of the removal rates of $\mathrm{Sb}, \mathrm{As}$, and Se through the existing APCDs, such as ESP/FFs and FGD, is difficult. The removal rates of $\mathrm{Sb}$, As, and Se by various control devices, such as WFGD, highly depend on the speciations of these elements in flue gas (elemental vs. oxidized forms) [18]. Oxidized metals can be easily removed in WFGD compared with its elemental forms. Coal properties, such as $\mathrm{Cl}$ content, affect the element speciation in the flue gas and in turn, the removal rate in WFGD [33]. Currently, actual measurements of Sb, As, and Se emission rates and species profiles from Shandong combustion facilities are still very limited, and the capture performance of $\mathrm{Sb}, \mathrm{As}$, and $\mathrm{Se}$ in Chinese emission control devices as well, especially for As and Se. The remaining uncertainties of our inventories can be reduced in future by additional field testing data for all types of coal and combustion facilities.

\section{Conclusions}

The calculated provincial total atmospheric emissions of Sb, As, and Se from coal combustion in Shandong rapidly increased from 40.26, 246.5, and $255.9 \mathrm{t}$ in 2005 to $51.35,311.9$, and $313.9 \mathrm{t}$ in 2014 , with annual growth rates of $2.75 \%, 2.65 \%$, and $2.27 \%$, respectively. Industrial use is the largest single contributor. Emissions of $\mathrm{Sb}, \mathrm{As}$, and Se from this sector reached 42.73, 257.6, and $233.1 \mathrm{t}$ in 2014 , accounting for $83.2 \%, 82.6 \%$, and $74.2 \%$ of the total emissions, respectively. The power plant sector is the second sector, contributing $23.5 \%, 26.0 \%$, and $33.3 \%$ of the total emissions of $\mathrm{Sb}$, As, and Se in 2005 , respectively. However, these amounts decreased to $7.89 \%, 9.31 \%$, and $14.3 \%$ in 2014.

Compared to the 2014 baseline, $\mathrm{Sb}$ and As would begin to decline from 2020 under the BACT and HECT scenarios, but emissions of Se in 2025 will still be higher than in 2014 in Shandong. By 2030, the approximate emission reductions of $7.43 \%$ for $\mathrm{Sb}$ and $20.4 \%$ for $\mathrm{As}$ can be achieved under the HECT scenario. Thus, the emissions of $\mathrm{Sb}$, As, and Se from coal-fired power plants can be controlled with the development of desulfurization and dust-removing devices.

\section{Acknowledgements}

This work was financially supported by the National Natural Science Foundation of China (No.41401255 and No.71402011), the Natural Science Foundation of Chongqing of China (No. cstc2015jcyjA20018), and the Key Laboratory of Hydraulic and Waterway Engineering of the Ministry of Education and National Engineering Research Center for Inland Waterway Regulation program (No. SLK2014A03). 


\section{References}

1. The People's Government of Shandong Province (PGSD) The Air Pollution Control Plan for Shandong Provinceduring 2013-2020 (in Chinese), 2013. http://sdgb.shandong.gov.cn/ art /2013/9/3 /art 4563 1906.html.

2. Shandong Province Environmental Bulletin, Environmental Protection Department of Shandong Province, 2014. http:// xxgk.sdein.gov.cn/xxgkml/hjzkgb/201506/t20150602 .html.

3. Shandong environment statistical data, Enverionmental protection department of Shandong province, 2014. http:// zlc.sdein.gov.cn/hjtj/201511/t20151103_286781.html.

4. CHENG H., ZHOU T., LI Q., LU L., LIN C. Anthropogenic Chromium Emissions in China from 1990 to 2009. PLoS ONE 9: e87753,2014.

5. LI H., WANG Q.G., SHAO M., WANG J., WANG C. Fractionation of airborne particulate-bound elements in haze-fog episode and associated health risks in a megacity of southeast China. Environmental Pollution 208, Part B: 655, 2016.

6. LI H., WANG J., WANG Q.G., QIAN X., QIAN Y. Chemical fractionation of arsenic and heavy metals in fine particle matter and its implications for risk assessment: A case study in Nanjing, China. Atmospheric Environment 103, 339, 2015.

7. LI H., QIAN X., WANG Q. Heavy Metals in Atmospheric Particulate Matter: A Comprehensive Understanding Is Needed for Monitoring and Risk Mitigation. Environmental Science \& Technology 47, 13210, 2013.

8. FILELLA M., BELZILE N., CHEN Y.W. Antimony in the environment: a review focused on natural waters I. Occurrence. Earth-Science Reviews 57, 125, 2002.

9. FILELLA M., BELZILE N., LETT M.C. Antimony in the environment: A review focused on natural waters. III. Microbiota relevant interactions. Earth-Science Reviews 80, 195, 2007.

10. GEBEL T. Arsenic and antimony: comparative approach on mechanistic toxicology. Chemico-Biological Interactions 107, 131, 1997

11. RAYMAN M.P. Selenium and human health. Lancet 379: 1256, 2012

12. TIAN H.Z., WANG Y., XUE Z.G., CHENG K., QU Y.P. Trend and characteristics of atmospheric emissions of $\mathrm{Hg}$, As, and Se from coal combustion in China, 1980-2007. Atmos Chem Phys 10, 11905, 2010.

13. National Health and Family Planning statistical yearbook, National Health and Family Planning Commission of the Peopless Republic of China, 2014, http://www.nhfpc.gov.cn/ zwgkzt/tjnj/list.shtml

14. ZHU J., WANG N., LI S., LI L., SU H. Distribution and transport of selenium in Yutangba, China: Impact of human activities. Science of The Total Environment 392, 252, 2008.

15. MAO D., SU H., YAN L. An epidemiologic investigation on selenium poisoning in southwestern Hubei Province. Chinese Journal of Endemiology 9 (5), 311, 1990.

16. TIAN H.Z., ZHAO D., HE M.C., WANG Y., CHENG K. Temporal and spatial distribution of atmospheric antimony emission inventories from coal combustion in China. Environmental Pollution 159, 1613, 2011.

17. MEIJ R., WINKEL H. The emissions of heavy metals and persistent organic pollutants from modern coal-fired power stations. Atmospheric Environment 41, 9262, 2007.

18. ONDOV J.M., RAGAINI R.C., BIERMANN A.H. Emissions and particle-size distributions of minor and trace elements at two western coal-fired power plants equipped with cold-side electrostatic precipitators. Environmental Science \& Technology 14, 1534, 1980.

19. SENIOR C.L., HELBLE J.J., SAROFIM A.F. Emissions of mercury, trace elements, and fine particles from stationary combustion sources. Fuel Processing Technology 65-66, 263, 2000.

20. YOKOYAMA T., ASAKURA K., MATSUDA H., ITO S., NODA N. Mercury emissions from a coal-fired power plant in Japan. Science of The Total Environment 259, 97, 2000.

21. CHEN J., LIU G., KANG Y., WU B., SUN R., ZHOU C., WU D. Atmospheric emissions of F, As, $\mathrm{Se}, \mathrm{Hg}$, and $\mathrm{Sb}$ from coal-fired power and heat generation in China, Chemoshere, 90, 1925, 2013

22. TANG S., FENG X., QIU J., YIN G., YANG Z. Mercury speciation and emissions from coal combustion in Guiyang, southwest China. Environmental Research 105, 175, 2007.

23. XIONG T., JIANG W., GAO W. Current status and prediction of major atmospheric emissions from coal-fired power plants in Shandong Province, China. Atmospheric Environment 124, Part A: 46, 2016.

24. ZHAO Y., WANG S., DUAN L., LEI Y., CAO P. Primary air pollutant emissions of coal-fired power plants in China: Current status and future prediction. Atmospheric Environment 42, 8442, 2008.

25. TIAN H., QU Y., WANG Y., PAN D., WANG X. Atmospheric selenium emission inventories from coal combustion in China in 2005. China Environmental Science 29, 1011, 2009.

26. CHENG K., WANG Y., TIAN H., GAO X., ZHANG Y. Atmospheric Emission Characteristics and Control Policies of Five Precedent-Controlled Toxic Heavy Metals from Anthropogenic Sources in China. Environmental Science \& Technology 49, 1206, 2015.

27. Ministry of Environmental Protection of China (MEP) Emission Standard of Air Pollutants for Thermal Power Plants.GB 13223-2011, Beijing, China, 2011.

28. Ministry of Environmental Protection of China (MEP) Ambient Air Quality Standards;GB 3095-2012. Beijing, China, 2012.

29. TIAN H.Z., ZHU C.Y., GAO J.J., CHENG K., HAO J.M. Quantitative assessment of atmospheric emissions of toxic heavy metals from anthropogenic sources in China: historical trend, spatial distribution, uncertainties, and control policies. Atmos Chem Phys 15, 10127, 2015.

30. Shandong Statistics Bureau (SDSB), Shandong Statistical Yearbook 2006-2015 (in Chinese). Beijing: China Statistics Press, 2006-2015.

31. China Electricity Council (CEC), China electric power yearbook. Beijing: China Electric Power Press, 2005-2015.

32. HELBLE J.J., MOJTAHEDI W., LYYRÄNEN J., JOKINIEMI J., KAUPPINEN E. Trace element partitioning during coal gasification. Fuel 75, 931, 1996

33. KLIKAZ., BARTOŇOVÁ L., SPEARS D.A. Effect of boiler output on trace element partitioning during coal combustion in two fluidised-bed power stations. Fuel 80, 907, 2001.

34. GOGEBAKAN Z., GOGEBAKAN Y., SELÇUK N., SELÇUK E. Investigation of ash deposition in a pilot-scale fluidized bed combustor co-firing biomass with lignite. Bioresource Technology 100, 1033, 2009.

35. OTERO-REY J.R., LÓPEZ-VILARIÑO J.M., MOREDAPIÑEIRO J., ALONSO-RODRÍGUEZ E., MUNIATEGUILORENZO S. As, Hg, and Se Flue Gas Sampling in a CoalFired Power Plant and Their Fate during Coal Combustion. Environmental Science \& Technology 37, 5262, 2003.

36. DAI S., REN D., CHOU C., FINKELMAN R., SEREDIN V., ZHOU Y. Geochemistry of trace elements in Chinese coals A review of abundances, genetic types, impacts on 
human health, and industrial utilization, Int. J. Coal Geol. 94, 3, 2012.

37. Shandong Statistics Bureau (SDSB), Shandong Statistical Yearbook 2013. Beijing: China Statistics Press, 2013.

38. DEMIR I., HUGHES R.E., DEMARIS P.J. Formation and use of coal combustion residues from three types of power plants burning Illinois coals. Fuel 80, 1659, 2001.

39. ÅMAND L.E., LECKNER B. Metal emissions from cocombustion of sewage sludge and coal/wood in fluidized bed. Fuel 83, 1803, 2004.

40. ZAJUSZ-ZUBEK E., KONIECZYŃSKI J. Dynamics of trace elements release in a coal pyrolysis process. Fuel $\mathbf{8 2}$, 1281, 2003.

41. GOGEBAKAN Z., SELÇUK N. Trace elements partitioning during co-firing biomass with lignite in a pilot-scale fluidized bed combustor. Journal of Hazardous Materials 162, 1129, 2009.

42. ONDOV J.M., RAGAINI R.C., BIERMANNA.H. Elemental emissions from a coal-fired power plant. Comparison of a venturi wet scrubber system with a cold-side electrostatic precipitator. Environmental Science \& Technology 13, 598, 1979. 